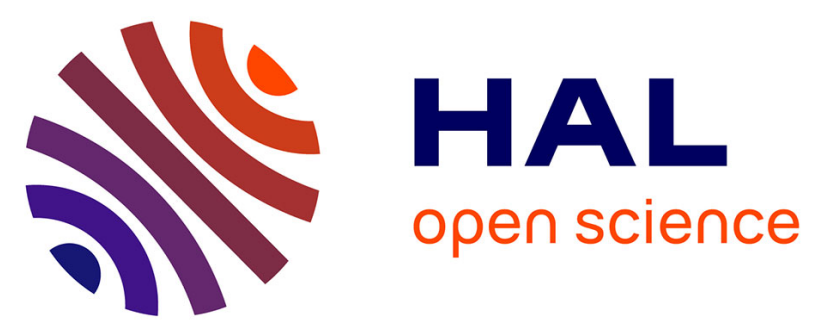

\title{
Effect of oral citrulline supplementation on whole body protein metabolism in adult patients with short bowel syndrome A pilot, randomized, double-blind, cross-over study
}

Adam Jirka, Sabrina Layec, Denis Picot, Silvia Bernon-Ferreira, Nadège

Grasset, Laurent Flet, Ronan Thibault, Dominique Darmaun

\section{To cite this version:}

Adam Jirka, Sabrina Layec, Denis Picot, Silvia Bernon-Ferreira, Nadège Grasset, et al.. Effect of oral citrulline supplementation on whole body protein metabolism in adult patients with short bowel syndrome A pilot, randomized, double-blind, cross-over study. Clinical Nutrition ESPEN, 2019, 38 (6), pp.2599-2606. 10.1016/j.clnu.2018.12.030 . hal-02020471

HAL Id: hal-02020471

https://hal-univ-rennes1.archives-ouvertes.fr/hal-02020471

Submitted on 7 Mar 2019

HAL is a multi-disciplinary open access archive for the deposit and dissemination of scientific research documents, whether they are published or not. The documents may come from teaching and research institutions in France or abroad, or from public or private research centers.
L'archive ouverte pluridisciplinaire HAL, est destinée au dépôt et à la diffusion de documents scientifiques de niveau recherche, publiés ou non, émanant des établissements d'enseignement et de recherche français ou étrangers, des laboratoires publics ou privés. 
Effect of oral citrulline supplementation on whole body protein metabolism in adult patients with short bowel syndrome: a pilot, randomized, doubleblind, cross-over study

Adam Jirka ${ }^{1,3}$, Sabrina Layec $^{2}$, Denis Picot $^{2}$, Silvia Bernon-Ferreira ${ }^{3}$, Nadège Grasset ${ }^{3,5}$, Laurent Flet ${ }^{4}$, Ronan Thibault ${ }^{6,7}$, Dominique Darmaun ${ }^{1,3}$

${ }^{1}$ Nutrition Support Team, Division of Gastroenterology, IMAD, University Hospital, Nantes, France

${ }^{2}$ Nutrition Department, Clinique St-Yves, Rennes, France

${ }^{3}$ INRA UMR 1280 PHAN, University of Nantes, IMAD, CRNH-Ouest

${ }^{4}$ Pharmacy Department, University Hospital, Nantes, France

${ }^{5}$ Department of Dietetics, University Hospital, Nantes, France

${ }^{6}$ Unité de Nutrition, CHU Rennes, Université Rennes 1, Rennes, France

${ }^{7}$ Institut NuMeCan, INSERM, INRA, Université Rennes 1, Rennes, France

Address for correspondence: Dominique Darmaun, MD, PhD, INRA UMR 1280, CHU Hotel-Dieu, 44093 Nantes Cedex 1, France; Telephone: 33-2 400842 75; e-mail: ddarmaun@chu-nantes.fr

Names for PubMed indexing: Jirka, Layec, Picot, Bernon-Ferreira, Grasset, Flet, Thibault, Darmaun

Clinical Trial Registry number: NCT01386034 in the www.clinicaltrials.gov website. 
1

3

4

\section{SUMMARY}

Background \& aims: As citrulline is produced by small intestine, plasma citrulline concentration is decreased and may become essential in patients with short bowel syndrome (SBS). In a rat model of SBS, citrulline supplementation enhanced muscle protein synthesis. The aim of the study was to determine whether citrulline impacts whole body protein metabolism in patients with SBS.

Methods: Nine adults with non-malignant SBS (residual small bowel $90 \pm 48 \mathrm{~cm}$; mean \pm SD) who were in near-normal nutritional status without any artificial nutrition, were recruited long after surgery. They received 7-day oral supplementation with citrulline $(0.18 \mathrm{~g} / \mathrm{kg} / \mathrm{day})$, or an iso-nitrogenous placebo in a randomized, double-blind, cross-over design with a 13-day washout between regimens, and an intravenous 5 -h infusion of $\mathrm{L}-\left[1-{ }^{13} \mathrm{C}\right]-$ leucine in the postabsorptive state to assess protein metabolism after each regimen.

Results: Plasma citrulline concentration rose 17 -fold (25 \pm 9 vs. $384 \pm 95 \mu \mathrm{mol} / \mathrm{L})$ and plasma arginine 3-fold after oral citrulline supplementation (both $\mathrm{p}<4 \times 10^{-6}$ ). Supplementation did not alter leucine appearance rate $\left(97 \pm 5 v s .97 \pm 5 \mu\right.$ mol. $\left.\mathrm{kg}^{-1} \cdot \mathrm{h}^{-1} ; \mathrm{p}=0.88\right)$, leucine oxidation $(14 \pm 1$ vs. $12 \pm 1 \mu \mathrm{mol} \cdot \mathrm{kg}^{-1} \cdot \mathrm{h}^{-1} ; \mathrm{p}=0.22$ ), or non-oxidative leucine disposal (NOLD), an index of whole-body protein synthesis $\left(83 \pm 4\right.$ vs. $85 \pm 5 \mu$ mol. $\left.\mathrm{kg}^{-1} \cdot \mathrm{h}^{-1} ; \mathrm{p}=0.36\right)$, nor insulin or IGF-1 plasma concentrations. In each of the 3 patients with baseline citrulline $<20 \mu \mathrm{mol} / \mathrm{L}$, citrulline supplementation increased NOLD. Among the 7 patients with plasma citrulline $<30 \mu \mathrm{mol} / \mathrm{L}$, the effect of supplementation on NOLD correlated inversely $\left(\mathrm{r}^{2}=0.81\right)$ with baseline plasma citrulline concentration.

Conclusion: 1) Oral citrulline supplementation enhances citrulline and arginine bioavailability in SBS patients. 2) Oral citrulline supplementation does not have any anabolic effect on whole body protein metabolism in patients with SBS in good nutritional status, in the late phase of 
25 intestinal adaptation, and with near-normal baseline citrulline homeostasis. 3) Whether oral

26 citrulline would impact whole body protein anabolism in severely malnourished SBS patients

27 in the early adaptive period, and with baseline plasma citrulline below $20 \mu \mathrm{mol} / \mathrm{L}$, warrants

28 further study. Registered under ClinicalTrials.gov Identifier no. NCT01386034

29 Keywords: Intestinal deficiency, Amino acids, Stable isotopes, Arginine

30

31 


\section{Introduction}

Short bowel syndrome (SBS) is defined by a residual small bowel length below $200 \mathrm{~cm}$ following intestinal resection. SBS initially results in intestinal failure [1] requiring intravenous delivery of nutrients and electrolytes. Weaning SBS patients off parenteral nutrition, however, often becomes feasible after several weeks or months, as oral food intake enhances intestinal adaptation [2]. In recent years, treatment with glucagon-like peptide 2 (GLP2) was proven to enhance intestinal mucosa growth [3], but GLP2 remains expensive, and is covered by health insurance only in the US and a few European countries. Moreover, as GLP-2 promotes crypt cell proliferation, treatment with GLP-2 analogs may, in theory, increase the risk of cancer. Even though GLP-2 was shown to promote tumor growth in animals with pre-existing cancer, treatment with GLP-2(1-33) up to 30 months was not found to increase the risk of cancer in humans without any known pre-existing neoplasia; the relatively small number of patients treated with GLP-2 analogs, however, precludes any final conclusion [4]. Although recombinant human growth hormone (rhGH) improved intestinal adaptation, no consensus has been reached regarding its use in SBS patients [5]. Even though glutamine is known to be the main fuel of enterocytes, glutamine supplementation failed to improve intestinal absorption or nutritional status in short bowel patients [6,7]. Whether other specific nutrients promote intestinal adaptation or lean body mass accretion remains to be explored $[6,7]$

Citrulline is a non-essential amino acid released by small intestine into portal blood [8], and is produced, in part, from glutamine metabolism in enterocytes $[9,10]$. Accordingly, glutamine supplementation increases citrulline availability in humans [11]. Crenn et al. were first to report a linear correlation between plasma citrulline concentration and residual small bowel length in SBS patients [12, and plasma citrulline was subsequently found to reflect functional intestinal enterocyte mass in several conditions associated with altered intestinal function [13- 
15]. Although citrulline is not incorporated into protein, it is taken up by kidney, where it is converted to arginine. Arginine, a semi-essential amino acid for protein synthesis, is known to exert anabolic effects through a stimulation of GH and insulin secretion in healthy humans [16]. Extensive small bowel resection depletes plasma arginine in rats, and is associated with negative nitrogen balance and slower growth, implying arginine may become conditionally essential in SBS [17]. Orally administered arginine, however, undergoes extensive first pass extraction in the splanchnic bed; oral arginine supplementation therefore often is relatively ineffective to increase systemic arginine availability. In contrast, citrulline, whether exogenous or endogenous, escapes splanchnic uptake, so oral citrulline supplementation is an attractive alternative to raise plasma arginine levels [18]. Osowska et al. were first to demonstrate that supplementation of enteral feeding with citrulline improved nitrogen balance and increased muscle protein synthesis in rats that had undergone extensive small intestinal resection [19]. An anabolic effect of citrulline supplementation on muscle protein synthesis was documented in other experimental models of undernutrition in aged, malnourished rats [20], or rat fetuses with intrauterine growth restriction due to maternal undernutrition [21]. Little is known about the putative effect of citrulline supplementation on protein metabolism in vivo in humans. Jourdan et al. found that orally supplemented citrulline increased skeletal muscle protein synthesis in healthy young men fed a low protein diet [22], with no detectable effect on whole body protein metabolism. In healthy young adults fed an adequate protein diet, we failed to observe any effect of oral citrulline supplementation on nitrogen balance nor on whole body protein kinetics [23].

The best of our knowledge, the effect of oral citrulline supplementation has yet to be explored in patients with SBS. We hypothesized that citrulline supplementation would enhance whole body protein synthesis in short bowel patients since (a) undernutrition and impaired protein absorption due to severe short bowel syndrome (extensive small bowel resection) would make 
82 arginine an essential amino acid. and (b) literature suggests citrulline had a protein anabolic 83 effect in several conditions associated with malnutrition in animals.

84

85 


\section{Patients and methods}

The study was designed as a bi-centric, prospective, randomized, double blind, cross-over trial, registered as NCT01386034 in the www.clinicaltrials.gov database (https://clinicaltrials.gov/ct2/show/NCT01386034). The primary objective was to determine whether oral citrulline supplementation would have an anabolic effect via a stimulation of whole body protein synthesis or a decrease in proteolysis-assessed using infusion of stable isotope labeled leucine (L- $\left[1-{ }^{13} \mathrm{C}\right]$ leucine $)-$ in short bowel patients.

\subsection{Study population}

Subjects were recruited among out-patients followed for short bowel syndrome by the Nutrition Support Team in the gastroenterology unit of University Hospital at Nantes, and Clinique St Yves at Rennes, specialized in intestinal rehabilitation. Prior to enrolment, each subject signed an informed consent form, according to protocols approved by the ethical committee of the Pays de La Loire region (CPP agreement \# 2011-00255-16 dated April 19, 2011).

Short bowel syndrome was defined as bowel length $<200 \mathrm{~cm}$ [24], or evidence for malabsorption from intestinal insufficiency. Though balance studies using fecal calorimetric analysis clearly are the 'gold standard' [2,25], many tests can be used to assess malabsorption such as a wet weight absorption $<1.41 \mathrm{~kg} / \mathrm{d}$, or an energy absorption $<84 \%$ of the calculated basal metabolic rate in 48-h metabolic balance studies [25]. Performance of balance studies, however, is cumbersome as it requires several days of stool collection and the availability of suitable equipment [26]. Similarly, the multiple probe sugar test can be used to assess both intestinal permeability (mostly in inflammatory bowel disease) [27] but is not routinely available in our hospital so we have no experience with its use. We accepted as evidence of malabsorption the presence of at least one of the following criteria: 
- output stoma >1.2 L/24h for an ileostomy; although high output stoma was defined as an output $>2 \mathrm{~L} / 24 \mathrm{~h}$ by Baker et al [28], there is no clear-cut definition of high output as multiple factors influence stoma output [29]; or $>300 \mathrm{~g} / 24 \mathrm{~h}$ for a colostomy

- steatorrhea $>15 \%$ of ingested fat, nitrogen loss $>20 \%$ of ingested protein $/ 24 \mathrm{hs}$, determined using a 3-day stool collection when data were available.

To be enrolled, patients also had to :

- Be between 18 and 75 years of age,

- Be in a stable condition, at least 6 months after the last gastrointestinal surgery,

- Be weaned from parenteral or enteral nutrition and on full oral nutrition,

- Receive no citrulline supplementation (commercially available in France as Stimol®),

- Be free of end stage kidney, pulmonary, or cardiac insufficiency,

- Be free of diabetes, and have a fasting blood glucose $<6 \mathrm{mmol} / \mathrm{L}$,

- Receive no glucocorticosteroid treatment,

- Be free of any active inflammatory disease (IBD, intercurrent infection...), chronic or acute pancreatitis, or cancer.

A sample of 12 patients was calculated to be sufficient to detect a $24 \%$ change in leucine oxidation, with an $\alpha$ risk of $10 \%$, and a power of $80 \%$.

\subsection{Study design.(Fig 1)}

A dietary history was obtained by an experienced dietician upon enrolment and before each tracer study. Patients were encouraged to maintain a constant oral intake particularly regarding protein intake (around $20 \%$ of total caloric intake), and to keep the same physical activity level during the study period. 
Each patient was admitted twice to the Clinical Research Center (CRC) of Nantes University Hospital for a half-day, within a 4-week interval. Before each admission, each patient received a one-week supplementation with oral natural L-citrulline $(0.18 \mathrm{~g} / \mathrm{kg} / \mathrm{day})$, or with an iso-nitrogenous placebo mixture constituted of an equimolar mix of 6 free amino acids: Lalanine, L-aspartic acid, L-glycine, L-histidine, L-proline and L-serine supplied by INRESA Pharma (France). The supplements were given in a blinded fashion as a powder in single dose vials that the patients had to dissolve in water at home. The list of randomization was established by the Pharmacy at Nantes University Hospital. The supplements were administered in randomized order, and separated by a 13-day wash-out period. A stable isotope infusion took place the day after the week of supplementation (citrulline or placebo). Each patient was used as his/her own control in a cross-over design. Patients and investigators were blinded as to the nature of the supplement administered.

A 5-hr, stable isotope infusion study was carried out on the $8^{\text {th }}$ and $29^{\text {th }}$ day of the study. In the morning of each tracer study, subjects reported to the CRC in the post-absorptive state after a 12-h overnight fast.

Weight, height, and body mass index (BMI) were measured at inclusion visit and before each of the tracer infusion studies. Body composition was evaluated by multi-frequency body impedance analysis (QuadScan $4000{ }^{\circledR}$, Bodystat ltd., UK). Additional blood samples were obtained for determination of plasma citrulline and arginine concentrations, serum electrolytes, albumin, thansthyretin, insulin, and insulin-like growth factor 1 (IGF-1). A urine sample was taken before and after the tracer infusion to determine urinary nitrogen, nitrite, and nitrate concentration.

At 08:00h, two catheters were inserted: the first catheter was placed in forearm vein for the stable isotope (L-[1- $\left.{ }^{13} \mathrm{C}\right]$ leucine) infusion. The second one was placed in a contralateral hand vein and used for blood sampling; the hand was placed in a heating pad to obtain arterialized 
venous blood at baseline, and 180, 200, 220, 240, 260, and 280 min after the start of isotope infusion to determine ${ }^{13} \mathrm{C}$-enrichment in plasma keto-isocaproate (KIC), the keto-acid of leucine. Throughout the tracer infusion, subjects were taking an oral dose of citrulline or placebo dissolved in water every $20 \mathrm{~min}$ but remained fasting otherwise through the end of tracer infusion. Plasma amino acid concentrations were measured after 180 min of isotope infusion while patients received q.20 min aliquots of either citrulline or 'placebo'.

Tracer infusion was started with a $6 \mu \mathrm{mol} . \mathrm{kg}^{-1}$ bolus injection at 08:00h (time 0 ), immediately followed by a continuous, 5-hr infusion at the constant rate of $6 \mu \mathrm{mol} \cdot \mathrm{kg}^{-1} \cdot \mathrm{h}^{-1}$ until 13:00h.

Simultaneously, overall rates of oxygen consumption $\left(\mathrm{VO}_{2}\right)$, carbon oxide production $\left(\mathrm{VCO}_{2}\right)$, and resting energy expenditure were measured for three 20-min periods over the course of isotope infusion via indirect calorimetry (Quark RMR®, Cosmed, Italy), and aliquots of expired air were collected at timed intervals over the last $2 \mathrm{hrs}$ of isotope infusion to define ${ }^{13} \mathrm{CO}_{2}$ enrichments.

At 13:00h, intravenous lines were removed, patients were fed, and discharged home to resume their routine treatment.

\subsection{Analytical methods}

Plasma citrulline was determined by liquid chromatography-tandem mass spectrometry (LCMSMS).

The ${ }^{13} \mathrm{C}$-enrichment in plasma KIC was measured by gas chromatography-mass spectrometry (GCMS) using a Hewlett-Packard-MSD 5971® instrument (Agilent Technologies Inc., Santa Clara, California, USA) in the Mass Spectrometry Platform of the Human Nutrition Research Center (CRNH-Ouest) at Nantes as described [30]. Plasma concentrations of leucine and KIC were determined by GCMS by reverse isotope dilution using labeled internal standards $\left({ }^{2} \mathrm{H}_{7}\right.$ - 
181 leucine and ${ }^{2} \mathrm{H}_{7}$-KIC). ${ }^{13} \mathrm{C}$-enrichment in expired ${ }^{13} \mathrm{CO}_{2}$ was determined by isotope-ratio mass

182

183

184

185

186

187

188

189

190

191

192

193

194

195

196

197

198

199

200

201

202

spectrometry coupled to gas chromatography (GC-IRMS) at the Biochemistry department of

Medical Faculty at Lausanne, Switzerland.

\subsection{Calculation of whole body leucine kinetics}

Leucine appearance into plasma $\left(\mathrm{Ra}, \mu \mathrm{mol} \cdot \mathrm{kg}^{-1} \cdot \mathrm{h}^{-1}\right)$, an index of whole body protein breakdown, was determined as $\mathrm{Ra}=\mathrm{i} \times[(\mathrm{Ei} / \mathrm{Ep})-1]$, where Ei and Ep represent ${ }^{13} \mathrm{C}$-enrichments (mole \% excess) in infused leucine and plasma KIC at steady state, respectively. Leucine oxidation $(\mathrm{Ox})$ was calculated as $\mathrm{Ox}=\mathrm{VCO}_{2} \times \mathrm{ECO}_{2} \times[(1 / \mathrm{EpKIC})-(1 / \mathrm{EiLeu})] / 0.81$; where $\mathrm{ECO}_{2}$ is ${ }^{13} \mathrm{C}$-enrichment in expired $\mathrm{CO}_{2}$ at steady state, and $\mathrm{VCO}_{2}$ is overall carbon dioxide measured using indirect calorimetry, and 0.81 corrects for incomplete ${ }^{13} \mathrm{C}$ recovery, as previously described [30].

Protein synthesis was estimated by non-oxidative leucine disposal (NOLD), using the equation: NOLD = Ra Leu - Ox.

\subsection{Statistics}

Statistical analysis was performed using the BiostaTGV: (http://marne.u707.jussieu.fr/biostatgv) and The R project for statistical computing software (https://www.R-project.org). Continuous variables are expressed as mean and standard deviation $( \pm \mathrm{SD})$. Wilcoxon test was used to compare the two treatments (Placebo and Citrulline). P-value $<0.05$ was considered statistically significant. 


\subsection{Patient characteristics}

205

206

207

208

209

210

211

212

213

214

215

216

217

218

219

220

221

222

Among the 11 patients enrolled in the study, 1 patient in each group withdrew his/her participation after the first regimen. A total of 9 patients (4 men and 5 women) completed the study between 2013 and 2015, and were included in analysis (Fig 2). The mean age was $64 \pm$ 11 years. The mean small intestine length was $93 \mathrm{~cm}$, ranging between 40 and $200 \mathrm{~cm}$. The etiology of short bowel syndrome, the remaining small and large bowel length and short bowel type as well as the time elapsed since last surgery. Anthropometric parameters confirmed all patients were in a normal nutrition status. The results of bioelectrical impedance analysis showed a fat mass and fat free mass of $24 \pm 3.94 \%$ and $76.1 \pm 3.32 \%$, respectively, in men, and $37.5 \pm 9.3 \%$ and $62.5 \pm 9.3 \%$ in women. All patients likely had developed hyperphagia with a mean energy intake of $45.4 \pm 16.2 \mathrm{kcal} \cdot \mathrm{kg}^{-1} \cdot \mathrm{d}^{-1}$ and a protein intake of $1.97 \pm 0.92 \mathrm{~g} \cdot \mathrm{kg}^{-1} \cdot \mathrm{d}^{-1}$.

Baseline serum albumin and prealbumin/transthyretin concentrations were $4.1 \pm 0.25 \mathrm{~g} / \mathrm{dL}$ and $23 \pm 2 \mathrm{mg} / \mathrm{dL}$, respectively, and plasma citrulline was $25 \pm 9 \mu \mathrm{mol} / \mathrm{L}$. (Table 1 ).

In theory, citrulline may have a long-lasting effect, and impact protein metabolism even after cessation of citrulline supplementation. Such putative, long-lasting effect, would, however, be unlikely to last more than a week, as is the case for alterations in leucine kinetics upon acute alterations of dietary protein intake. This was the rationale for the 2-week washout period inbetween the citrulline and placebo supplementation periods. According to the cross-over design (Fig 1), 5 patients received citrulline supplementation first, followed by placebo, whereas were assigned to the opposite sequence. We did not detect any difference between patients who received placebo first and those who received citrulline first. No side effect was observed in either group. 


\subsection{Effect of citrulline supplementation on plasma amino acid, insulin and IGF-1} concentrations

Plasma citrulline rose 17-fold with supplementation (Citrulline vs. Placebo : $384 \pm 95$ vs. $25 \pm$ $9 \mu \mathrm{mol} / \mathrm{L}, \mathrm{p}<0.05$ ) (Table 2). Plasma arginine concentration rose 3 -fold (Citrulline vs. Placebo: $146 \pm 28 v s .47 \pm 19 \mu \mathrm{mol} / \mathrm{L}, \mathrm{p}<0.05$ ), and plasma ornithine 2-fold (Citrulline $v s$. Placebo: $135 \pm 18$ vs. $54 \pm 14 \mu \mathrm{mol} / \mathrm{L}, \mathrm{p}<0.05)$. Plasma glutamine and leucine concentrations were not affected by citrulline supplementation (Table 2). As expected, the plasma concentrations of the non-essential amino acids supplied as part of the placebo regimen were higher on the placebo day (Table 2). There was no statistically significant difference in the plasma concentrations of IGF-1 and insulin (data not shown).

\subsection{Effect of citrulline supplementation on protein metabolism.}

There was no significant difference in plasma ${ }^{13} \mathrm{C}$-KIC enrichment ( $6.03 \pm 0.88$ vs. $6.09 \pm$ 0.92 mole \% excess, MPE) nor in expired ${ }^{13} \mathrm{CO}_{2}(0.009 \pm 0.001$ vs. $0.009 \pm 0.002 \mathrm{MPE})$ when comparing Citrulline vs. Placebo, and, consequently, no detectable effect on leucine oxidation, whether results were expressed per kg of body weight (Fig 3) or kg of FFM (data not shown).

Similarly, plasma ${ }^{13} \mathrm{C}-\mathrm{KIC}$ enrichment did not differ between study days, so oral supplementation with citrulline did not affect leucine Ra, oxidation, or estimates of leucine incorporation into protein (NOLD). This held true whether results were expressed per $\mathrm{kg}$ of body weight or per of $\mathrm{kg}$ of fat free mass (data not shown).

Among the 9 patients enrolled, three (\#2, 3, and 4) had a baseline citrulline of 13, 20, and 11 $\mu \mathrm{mol} / \mathrm{L}$, i.e., at or below $20 \mu \mathrm{mol} / \mathrm{L}$, a threshold found to associate with the persistent need for 
251 parenteral nutrition in earlier studies [12]. In the latter 3 patients, citrulline supplementation was consistently associated with a rise in NOLD (from 85.9 to $91.3 ; 70.3$ to 72.6 ; and 77.4 to

253 $83.5 \mu \mathrm{mol} \cdot \mathrm{kg}^{-1} \cdot \mathrm{h}^{-1}$ in subjects \#2,3 and 4 , respectively).

254 Conversely, 2 patients (\#7 and 9) had a baseline citrulline $>30 \mu \mathrm{mol} / \mathrm{L}$ (39 and $35 \mu \mathrm{mol} / \mathrm{L}$ in 255 subjects \#7 and 9, respectively). If the latter 2 patients were excluded from analysis, a tight 256 correlation would be apparent between the change in NOLD associated with citrulline 257 supplementation and baseline plasma citrulline concentration (Fig. 4). 


\section{Discussion}

To the best of our knowledge, the current study is first to explore the effect of oral citrulline supplementation in patients with short bowel syndrome. We demonstrate that oral citrulline supplementation can efficiently raise the concentration of plasma citrulline and arginine in humans after extensive small intestinal resection. Citrulline supplementation, however, did not enhance whole body protein accretion under the conditions tested.

Our study documents the bioavailability of citrulline during oral supplementation of citrulline in short bowel patients. The 17- and 3-fold rise in the plasma concentration of citrulline and arginine, respectively, suggests that 1) citrulline may be predominantly absorbed in the proximal small bowel (duodenum, jejunum) since most of our patients had a very short residual ileum; 2) splanchnic citrulline uptake is likely low, and 3) citrulline conversion to arginine is unaltered in short bowel patients in the absence of renal insufficiency.

Since arginine has long been known to stimulate GH and insulin secretion, we measured the concentrations of IGF1 and insulin with or without citrulline supplementation, and did not find any significant difference between the two periods (Citrulline vs. Placebo), consistent with our earlier findings using the same dose of citrulline in healthy subjects [23].

The lack of any protein anabolic effect of citrulline supplementation in the current study contrasts with the dramatic anabolic effect of citrulline documented in enterectomized rats [20]. Besides obvious differences between species, several factors could account for such discrepancy, including 1) a type 2 statistical error; 2) the characteristics of the patient population sample; and 3) a true lack of any anabolic effect of citrulline either on whole body or muscle protein metabolism. These potential causes are addressed below.

The first potential explanation is the small number of patients enrolled in the study. We encountered difficulties in recruiting the number of 12 patients suggested by our initial 
calculation of statistical power. In theory, we may have missed a true anabolic effect of citrulline on whole body leucine kinetics because only 9 patients completed the 2 arms of the study. Yet no consistent pattern was observed: with citrulline supplementation, NOLD increased in 4 patients, but decreased in 5, and the mean change in NOLD was less than 1 $\mu$ mol. $\mathrm{kg}^{-1} \cdot \mathrm{h}^{-1}$ (i.e., $<1 \%$ of NOLD), between regimens. The number of 12 patients was calculated based on the assumption that it would be large enough to detect a $24 \%$ change in leucine oxidation, with an $\alpha$ risk of $10 \%$, and a power of $80 \%$. In the 9 patients enrolled, we observed a change in leucine oxidation of only $\approx 10 \%$, from $13.8 \pm 3.6 \mu \mathrm{mol} \cdot \mathrm{kg}^{-1} \cdot \mathrm{h}^{-1}$ with placebo to $12.3 \pm 3.6 \mu \mathrm{mol} \cdot \mathrm{kg}^{-1} \cdot \mathrm{h}^{-1}$ with citrulline supplementation. The putative number of patients required to reach statistical significance with such change can be re-calculated as $n=2$ $+\mathrm{C}(\sigma / \delta)^{2}$ where $\mathrm{C}=7.85$ for an $\alpha$ risk of $<0.05$, and a power $(1-\beta)$ of $80 \%$, and $\sigma^{2}$ is the variance of the measured parameter, and $\delta$ is the expected difference between the two studies on the measured parameter [31]. In our case, the measured parameter is leucine oxidation, $\delta$ is 13.8-12.3=1.5, and $\sigma=3.6$, so $(\sigma / \delta)=3.6 / 1.5=2.4$; therefore $n=2+7.85 \times(2.4)^{2}=2+(7.85 \times$ $5.8)=47$. As short bowel syndrome is a relatively rare disease, recruiting 47 patients from our unit seemed unrealistic to us, and we therefore elected to report our observation as a preliminary, 'pilot' study instead.

A second factor may be the characteristics of the sample population. Whereas the enterectomized rats that benefited from citrulline supplementation showed evidence of severe malnutrition in the study by Oszowska et al [19], patients enrolled in the current study did not show any evidence of undernutrition. The normal body mass index $\left(23.97 \pm 3.69 \mathrm{~kg} \cdot \mathrm{m}^{-2}\right)$, fat free mass $(71 \pm 11 \%)$, and normal serum albumin $\left(4.1 \pm 0.25 \mathrm{~g} \cdot \mathrm{dL}^{-1}\right)$ and prealbumin $(23 \pm 2$ $\mathrm{mg} / \mathrm{dL}$ ) together suggest that our patients were not significantly undernourished. Moreover, in the current study, the time elapsed since last surgery was, on average, 23 months; such time laps was likely long enough for intestinal adaptation to have taken place between intestinal 
resection and enrolment in the current study. All patients indeed presented with high dietary intakes, suggesting compensatory hyperphagia, which is an important determinant of intestinal adaptation, and all had been successfully weaned off home parenteral nutrition (HPN). HPN independence was one of the inclusion criteria, to avoid any potential effect of parenteral amino acid infusion on protein metabolism. In contrast, in the study by Osowska et al., enterectomized rats received citrulline supplementation only 4 days after surgery [17]. Among our patients, no effect of citrulline was observed even in the subgroup of patients who had undergone surgery less than 1 year prior to study and who would meet the criteria for type II intestinal failure (prolonged acute condition for weeks to months) [1].

The baseline plasma citrulline concentration of $25 \pm 9 \mu$ mol/L (mean $\pm \mathrm{SD}$ ) observed in our patients, was similar to the $27 \pm 5 \mu \mathrm{mol} / \mathrm{L}$ measured in our earlier study in healthy volunteers [23], and consistent with the fact that our patients had achieved full intestinal adaptation before the study. Crenn et al. found a concentration of citrulline $>20 \mu \mathrm{mol} / \mathrm{L}$ to predict successful HPN weaning [9]. Even though subgroup analysis cannot be statistically valid on small groups, we attempted to better characterize responders versus non-responders. In our study, citrulline supplementation was consistently associated with a protein anabolic response in the 3 patients at or below that threshold (data not shown). The reason for the lower baseline plasma citrulline concentration in that subset of patients is unclear. Postabsorptive plasma citrulline concentration was shown to be decreased, not only in short bowel syndrome but in many other conditions such as radiation enteritis [14], intestinal graft rejection [15], active coeliac disease with villous atrophy [13], or transient enterostomy—for instance plasma citrulline was decreased in patients with enterostomy, and rose after chime reinfusion [32]. This is why citrulline has emerged as a biomarker of functional intestinal mass [34]. Whether a short transit time per se, regardless of its cause, impacts plasma citrulline, has not, to our knowledge, been investigated. In theory, a rapid transit time may decrease amino acid 
absorption from intestinal lumen by decreasing the time of exposure of nutrients to intestinal mucosa, and reduce the absorption of amino acid precursors of citrulline, such as glutamine or proline [9-11]. In the current study, in the small sample population studied, we did not observe any obvious relationship between the etiology of short bowel syndrome, the number of stools per day, and plasma citrulline.

These 3 patients had the shorter residual small bowel length; they tended to have low transthyretin, 2 had a distal ileum and an entire colon in continuity, 2 had a delay after surgery of $<1 \mathrm{yr}$ (Table 1); they did not appear to differ from the rest regarding age, energy or protein intake, weight, BMI, and lean body mass, nor regarding the effect of citrulline supplementation on IGF-1. Yet animal studies suggest citrulline may exert its putative protein anabolic effect directly through the PI3K/MAPK/4E-BP1 pathway, a signaling pathway involved in the regulation of protein synthesis [34]. The response of NOLD to citrulline supplementation may indeed depend on baseline citrulline concentration: when the 2 patients with the higher baseline plasma citrulline concentration $(>30 \mu \mathrm{mol} / \mathrm{L})$ were excluded from analysis, a tight correlation was observed between the response of NOLD, an index of whole body protein synthesis, and baseline plasma citrulline (Fig 3); in other words, the lower the baseline plasma citrulline concentration, the more anabolic effect was observed upon citrulline supplementation. Although such small sample size precludes any firm conclusion, those preliminary results strongly suggest that citrulline supplementation may have a protein anabolic role in patients who are truly citrulline deficient.

A limitation of our study is the fact that we did not quantitate intestinal absorption nor intestinal permeability, so our patients likely had various degrees of fat and protein malabsorption.

Another limitation of our study is the fact we explored the effect of citrulline solely on whole body protein metabolism. In the study by Jourdan et al, even though citrulline enhanced 
fractional synthesis rate in skeletal muscle in healthy volunteers fed a low protein diet, no effect of citrulline was detected at the whole body level [22]. Similarly, in previous studies, we failed to observe any effect of oral citrulline supplementation on whole body protein metabolism in healthy volunteers [23]. A recent study showed a significant rise in appendicular skeletal muscle mass evaluated by DEXA scan, in malnourished, elderly women after 3 weeks of oral citrulline supplementation [35]. Taken together, literature thus suggests that the protein anabolic effect of citrulline may be specific to skeletal muscle [36].

The main strength of the current study nevertheless stems from the fact that this is the first pilot trial of oral citrulline in a carefully selected, relatively homogenous group of patients with short bowel syndrome explored with sensitive methods to detect any change in whole body protein metabolism.

\section{Conclusion}

The results of our study demonstrate that oral citrulline supplementation can increase citrulline and arginine bioavailability in short bowel patients. They further suggest that oral citrulline supplementation does not have any anabolic effect on whole body protein metabolism in patients with short bowel syndrome in good nutritional status, in the late phase of intestinal adaptation, and with near-normal baseline citrulline homeostasis. Whether oral citrulline would impact whole body or skeletal muscle protein anabolism in short-bowel patients in the early adaptive period, who are severely malnourished, and/or have plasma citrulline below $20 \mu \mathrm{mol} / \mathrm{L}$, would clearly warrant further study.

\section{Authors' contribution}


Author Contributions: AJ and DD had full access to all of the data in the study and take responsibility for the integrity of the data and the accuracy of the data analysis.Study concept and design: AJ, DP, RT, DD

Acquisition, analysis, or interpretation of data: All authors

Drafting of the manuscript: AJ, DD

Critical revision of the manuscript for important intellectual content: All authors

Statistical analysis: AJ, DD

Study supervision: AJ, DD

\section{Funding}

This study was supported, in part, by Interregional PHRC Grand-Ouest (grant \#BRD09/W), and the 2012 URGO Prize. No funder/sponsor had any role in the design and conduct of the study; collection, management, analysis, and interpretation of the data; preparation, review, or approval of the manuscript; or decision to submit the manuscript for publication.

\section{Conflict of interest statement}

None for any of the authors.

\section{Acknowledgments}

The authors are indebted to Eliane Hivernaud, Stéphanie Bardot, and Fabienne Vavasseur for their dedicated care of the subjects enrolled in the clinical protocol, to Mikael Croyal, Véronique Ferchaud-Roucher, and Audrey Aguesse for their skillful help in mass spectrometry analyses as well to Dr Philippe Schneiter from Department of physiology at 
402 Medicine faculty of Lausanne University, Switzerland for the ${ }^{13} \mathrm{CO}_{2}$ enrichment analysis.

403

404

405 


\section{References}

[1] Pironi L, Arends J, Baxter J, Bozzetti F, Peláez RB, Cuerda C, Forbes A, Gabe S, Gillanders L, Holst M, Jeppesen PB, et al. ESPEN endorsed recommendations: Definition and classification of intestinal failure in adults. Clin Nutr 2015;34:171-80.

[2] Crenn P, Morin MC, Joly F, Penven S, Thuillier F. Net digestive absorption and adaptive hyperphagia in adult short bowel patients. Gut 2004; 53:1279-86.

[3] Jeppesen PB, Sanguinetti EL, Buchman A, Howard L, Scolapio JS, Ziegler TR, Gregory J, Tappenden KA, Holst J, Mortensen PB. Teduglutide (ALX-0600), a dipeptidyl peptidase IV resistant glucagon-like peptide 2 analogue, improves intestinal function in short bowel syndrome patients. Gut 2005;54:1224-31.

[4] Ring LL, Nerup N, Jeppesen PB, Svendsen LB, Achiam MP. Glucagon like peptide-2 and neoplasia; a systematic review. Expert Rev Gastroenterol Hepatol 2018; 12: 257-264

[5] Seguy D, Vahedi K, Kapel N, Souberbielle J, Messing B. Low-dose growth hormone in adult home parenteral nutrition-dependent short bowel syndrome patients: A positive study. Gastroenterology 2003;124:293-302.

408 [6] Scolapio JS, McGreevy K, Tennyson GS, Burnett OL. Effect of glutamine in short409 bowel syndrome. Clin Nutr 2001; 20:319-323.

[7] Sax HC. Specific nutrients in intestinal failure: one size fits no one. Gastroenterology 2006; 130(2 Suppl 1):S91-92

[8] Windmueller HG, Spaeth AE. Source and fate of circulating citrulline. Am J Physiol 
1981;241: 473-80.

[9] Ligthart-Melis GC, van de Poll MC, Vermeulen MA, Boelens PG, van den Tol MP, van Schaik C, De Bandt JP, Deutz NE, Dejong CH, van Leeuwen PA. Enteral administration of alanyl-[2-(15)N]glutamine contributes more to the de novo synthesis of arginine than does intravenous infusion of the dipeptide in humans. Am J Clin Nutr 2009;90:95-105.

[10] Tomlinson C, Rafii M, Ball RO, Pencharz P. Arginine synthesis from enteral glutamine in healthy adults in the fed state. Am J Physiol 2011; 301: E267-73.

[11] Déchelotte P, Darmaun D, Rongier M, Hecketsweiler B, Rigal O, Desjeux JF. Absorption and metabolic effects of enterally administered glutamine in humans. Am $\mathbf{J}$ Physiol 1991;260:E 677-82.

[12] Crenn P, Coudray-Lucas C, Thuillier F, Cynober L, Messing B. Postabsorptive plasma citrulline concentration is a marker of absorptive enterocyte mass and intestinal failure in humans. Gastroenterology 2000;119:1496-505.

[13] Crenn P, Vahedi K, Lavergne-Slove A, Cynober L, Matuchansky C, Messing B. Plasma citrulline: A marker of enterocyte mass in villous atrophy-associated small bowel disease. Gastroenterology 2003;124:1210-9.

[14] Lutgens LC, Deutz N, Granzier-Peeters M, Beets-Tan R, De Ruysscher D, Gueulette J, Cleutjens J, Berger M, Wouters B, von Meyenfeldt $\mathrm{M}$, et al. Plasma citrulline concentration: A surrogate end point for radiation-induced mucosal atrophy of the small bowel. A feasibility study in 23 patients. Int J Radiat Oncol 2004;60:275-85.

[15] Pappas PA, G. Tzakis A, Gaynor JJ, Carreno MR, Ruiz P, Huijing F, Huijing F, Kleiner G, Rabier D, Kato T, et al. An analysis of the association between serum 
citrulline and acute rejection among 26 recipients of intestinaltTransplant. Am $\mathbf{J}$ Transplant 2004;4:1124-32.

[16] Witte MB, Barbul A. Arginine physiology and its implication for wound healing. Wound Repair Regen. 2003; 11:419-423.

[17] Wakabayashi Y, Yamada E, Yoshida T, Takahashi N. Effect of intestinal resection and arginine-free diet on rat physiology. Am J Physiol 1995; 269: G313-8.

[18] Rougé C, Des Robert C, Robins A, Le Bacquer O, Volteau C, De La Cochetière M-F, Darmaun D. Manipulation of citrulline availability in humans. Am J Physiol 2007;293:G1061-1067.

[19] Osowska S, Moinard C, Neveux N, Loï C, Cynober L. Citrulline increases arginine pools and restores nitrogen balance after massive intestinal resection. Gut 2004; $53: 1781-6$.

[20] Osowska S, Duchemann T, Walrand S, Paillard a, Boirie Y, Cynober L, Moinard C. Citrulline modulates muscle protein metabolism in old malnourished rats. Am J Physiol Endocrinol Metab 2006; 291: 582-6.

[21] Bourdon A, Parnet P, Nowak C, Tran N, Winer N, Darmaun D. L -Citrulline Supplementation Enhances Fetal Growth and Protein Synthesis in Rats with. J Nutr 2016; 146:532-41.

[22] Jourdan M, Nair KS, Carter RE, Schimke J, Ford GC, Marc J, Aussel C, Cynober L. Citrulline stimulates muscle protein synthesis in the post-absorptive state in healthy people fed a low-protein diet - A pilot study. Clin Nutr 2015; 34:449-56. 
[23] Thibault R, Flet L, Vavasseur F, Lemerle M, Ferchaud-Roucher V, Picot D, Darmaun D. Oral citrulline does not affect whole body protein metabolism in healthy human volunteers: Results of a prospective, randomized, double-blind, cross-over study. Clin Nutr 2011; 30:807-11.

[24] Pironi L, Arends J, Bozzetti F, Cuerda C, Gillanders L, Jeppesen PB, et al.ESPEN guidelines on chronic intestinal failure in adults. Clin Nutr 2016; 35:247-307

[25] Jeppesen PB, Mortensen PB. Intestinal failure defined by measurements of intestinal energy and wet weight absorption. Gut 2000;46:701-706]

[26] O'Keefe SJ, Buchman AL, Fishbein TM, Jeejeebhoy KN, Jeppesen PB, Shaffer J. Short bowel syndrome and intestinal failure: consensus definitions and overview. Clin Gastroenterol Hepatol 2006; 4:6-10

[27] Rooyakkers DR, van Eijk HM, Deutz NE. Simple and sensitive multi-sugar-probe gut permeability test by high-performance liquid chromatography with fluorescence labelling. J Chromatogr A 1996; 730:99-105]

[28] Baker ML, Williams RN, Nightingale JM. Causes and management of a high-output stoma. Colorectal Dis 2011; 13:191-7]

[29] Management of acute intestinal failure: A position paper from the European Society for Clinical Nutrition and Metabolism (ESPEN) Special Interest Group: Klek S, Forbes A, Gabe S, Holst M, Wanten G, Irtun $\varnothing$, Damink SO, Panisic-Sekeljic M, Burgos Pelaez R, Pironi L, Reintam Blaser A, Højgaard Rasmussen H, Schneider SM, Thibault R, Visschers RGJ, Shaffer J. Clin Nutr 2016; 35: 1209-1218

[30] Bourreille A, Humbert B, Maugère P, Galmiche JP, Darmaun D. Glutamine metabolism in Crohn's disease: a stable isotope study. Clin Nutr 2004; 23:1167-75 
[31] Friedman LM. Sample size. In: Fundamentals of clinical trials. John Wright, Boston, 1983.

411 [32] Picot D, Garin L, Trivin F, Kossovsky MP, Darmaun D, Thibault R. Plasma citrulline is 412 a marker of absorptive small bowel length in patients with transient enterostomy and acute 413 intestinal failure. Clin Nutr 2010; 29:235-42.

414

[33] Fragkos KC, Forbes A. Citrulline as a marker of intestinal function and absorption in 416 clinical settings: A systematic review and meta-analysis. United European Gastroenterol J. 417 2018; 6:181-191

[34] Le Plénier S, Goron A, Sotiropoulos A, Archambault E, Guihenneuc C, Walrand S,

Salles J, Jourdan M, Neveux N, Cynober L, Moinard C. Citrulline directlymodulates muscle protein synthesis via the PI3K/MAPK/4E-BP1 pathway in a

malnourished state: evidence from in vivo, ex vivo, and in vitro studies. Am J

Physiol 2017;312:E27-E36.

418 [35] Bouillanne O, Melchior JC, Faure C, Canouï-Poitrine F, Paul M, Boirie Y, et al. Effects

419 of citrulline (CIT) oral supplementation during 21 Days on body composition in malnourished

420 elderly patients. Clin Nutr 2015;34:S27e8.

421 [36] Papadia C, Osowska S, Cynober L, Forbes A. Citrulline in health and disease.

Review on human studies. Clin Nutr 2017 Oct 16. pii: S0261-5614(17)31369-9. 


\section{Table 1}

423 Etiology and anatomic characteristics of short bowel syndrome (SBS), baseline 424 anthropometric data, body composition from bioelectrical impedance analysis (BIA), and 425 dietary intake in enrolled patients; WT: body weight; IBW: ideal body weight; MI: 426 mesenterich ischemia; Radiation: post-radtion enteritis; Crohn: Crohn's disease; Type of SBS:

427 type I: SBS with end jeunostomy; type II; SBS with jejuno-colic anastomosis; type III: ileo428 jeuno-colic anastomosis.

\begin{tabular}{|c|c|c|c|c|c|c|c|c|c|c|c|c|c|c|}
\hline Patient & $\begin{array}{c}\text { Age } \\
\text { yrs }\end{array}$ & $\begin{array}{c}\text { Wt } \\
\mathrm{kg}\end{array}$ & $\begin{array}{c}\text { BMI } \\
\mathrm{kg} / \mathrm{m}^{2}\end{array}$ & $\begin{array}{c}\% \text { of } \\
\mathrm{IBW}\end{array}$ & $\begin{array}{c}\text { Fat } \\
\text { free } \\
\text { mass } \\
\%\end{array}$ & $\begin{array}{c}\text { SBS } \\
\text { etio- } \\
\text { logy }\end{array}$ & $\begin{array}{c}\text { SBS } \\
\text { type }\end{array}$ & $\begin{array}{c}\text { Rem- } \\
\text { nant } \\
\text { small } \\
\text { bowel } \\
\text { length } \\
\mathrm{cm}\end{array}$ & $\begin{array}{c}\text { Rem- } \\
\text { nant } \\
\text { colon } \\
\%\end{array}$ & $\begin{array}{c}\text { Time } \\
\text { since } \\
\text { surgery } \\
\text { (months) }\end{array}$ & $\begin{array}{c}\text { Plasma } \\
\text { citrul- } \\
\text { line } \\
\mu \mathrm{mol} / \\
\mathrm{L}\end{array}$ & $\begin{array}{c}\text { Plasma } \\
\text { Creati- } \\
\text { nine } \\
\mu \mathrm{mol} / \\
\mathrm{L}\end{array}$ & $\begin{array}{c}\text { Dietary } \\
\text { energy } \\
\text { intake } \\
\mathrm{kcal} / \mathrm{kg} / \mathrm{d}\end{array}$ & $\begin{array}{c}\text { Dietary } \\
\text { protein } \\
\text { intake } \\
\mathrm{g} / \mathrm{kg} / \mathrm{d}\end{array}$ \\
\hline 1 & 64 & 61.5 & 23.7 & 106 & 75 & MI & II & 120 & 71 & 169 & 27 & 91 & 40 & 1.9 \\
\hline 2 & 75 & 61 & 23.5 & 155 & 73 & MI & II & 50 & 57 & 88 & 13 & 66 & 55 & 2.5 \\
\hline 3 & 64 & 67 & 23.3 & 104 & 76 & $\begin{array}{c}\text { Volv- } \\
\text { ulus }\end{array}$ & III & 65 & 100 & 11 & 20 & 96 & 36 & 1.4 \\
\hline 4 & 41 & 72 & 29.2 & 133 & 62 & MI & III & 40 & 100 & 10 & 11 & 56 & 22 & 1.0 \\
\hline 5 & 55 & 60 & 20.0 & 94 & 76 & $\begin{array}{c}\text { Radia- } \\
\text { tion }\end{array}$ & II & 100 & 71 & 55 & 24 & 94 & 41 & 1.8 \\
\hline 6 & 71 & 52 & 20.6 & 94 & 55 & MI & I & 200 & 0 & 23 & 28 & 79 & 73 & 3.9 \\
\hline 7 & 69 & 66.5 & 21.1 & 94 & 79 & MI & II & 100 & 85 & 138 & 39 & 69 & 46 & 2.3 \\
\hline 8 & 66 & 68 & 29.9 & 135 & 56 & MI & II & 70 & 71 & 8 & 28 & 73 & 31 & 1.1 \\
\hline 9 & 49 & 70 & 21.5 & 96 & 87 & Crohn & II & 200 & 71 & 378 & 35 & 119 & 38 & 1.5 \\
\hline $\begin{array}{c}\text { mean } \\
\pm \text { SD }\end{array}$ & 61 & 64 & 23 & 107 & 71 & & & 90 & 70 & 63 & 25 & 82 & 42 & $1.9 \pm 0.8$ \\
\pm 11 & \pm 6 & \pm 3.6 & \pm 16 & $\pm 11)$ & & & \pm 48 & \pm 30 & \pm 63 & \pm 9 & \pm 19 & \pm 14 \\
\hline median & 64 & 66 & 23.3 & 104 & 75 & & & 70 & 71 & 39 & 27 & 79 & 40 & 1.8 \\
\hline
\end{tabular}


Table 2

435 Effect of citrulline or placebo supplementation on plasma amino acid concentrations in short bowel patients.

\begin{tabular}{|c|c|c|c|}
\hline & Placebo & Citrulline & $\mathrm{p}$ \\
\hline Aminoisobutyric acid & $17 \pm 4$ & $14 \pm 4$ & 0.22 \\
\hline Alanine & $342 \pm 165$ & $283 \pm 188$ & 0.25 \\
\hline Arginine & $54 \pm 31$ & $164 \pm 41$ & $3.5 \times 10^{-6}$ \\
\hline Asparagine & $45 \pm 10$ & $39 \pm 6$ & 0.10 \\
\hline Aspartic acid & $5 \pm 4$ & $2 \pm 1$ & 0.03 \\
\hline Citrulline & $26 \pm 10$ & $384 \pm 95$ & $3.5 \times 10^{-6}$ \\
\hline Cysteine & $38 \pm 22$ & $47 \pm 33$ & 0.25 \\
\hline Glutamine & $578 \pm 165$ & $567 \pm 112$ & 0.88 \\
\hline Glutamic acid & $43 \pm 18$ & $36 \pm 12$ & 0.09 \\
\hline Glycine & $369 \pm 96$ & $230 \pm 44$ & 0.006 \\
\hline Histidine & $156 \pm 77$ & $64 \pm 17$ & 0.003 \\
\hline Isoleucine & $51 \pm 10$ & $53 \pm 10$ & 0.83 \\
\hline Leucine & $96 \pm 11$ & $102 \pm 13$ & 0.63 \\
\hline Lysine & $158 \pm 48$ & $139 \pm 30$ & 0.31 \\
\hline Methionine & $18 \pm 4$ & $16 \pm 3$ & 0.49 \\
\hline Ornithine & $61 \pm 23$ & $163 \pm 48$ & $3.4 \times 10^{-5}$ \\
\hline Phenylalanine & $40 \pm 11$ & $41 \pm 10$ & 0.5 \\
\hline Proline & $239 \pm 78$ & $176 \pm 31$ & 0.14 \\
\hline Serine & $143 \pm 45$ & $73 \pm 15$ & 0.002 \\
\hline Taurine & $50 \pm 21$ & $49 \pm 14$ & 0.65 \\
\hline Threonine & $88 \pm 32$ & $71 \pm 19$ & 0.14 \\
\hline Tryptophan & $34 \pm 11$ & $29 \pm 9$ & 0.08 \\
\hline Tyrosine & $37 \pm 11$ & $37 \pm 9$ & 0.96 \\
\hline Valine & $158 \pm 17$ & $157 \pm 25$ & 0.99 \\
\hline
\end{tabular}


439 Fig 1. Study design.

440

441
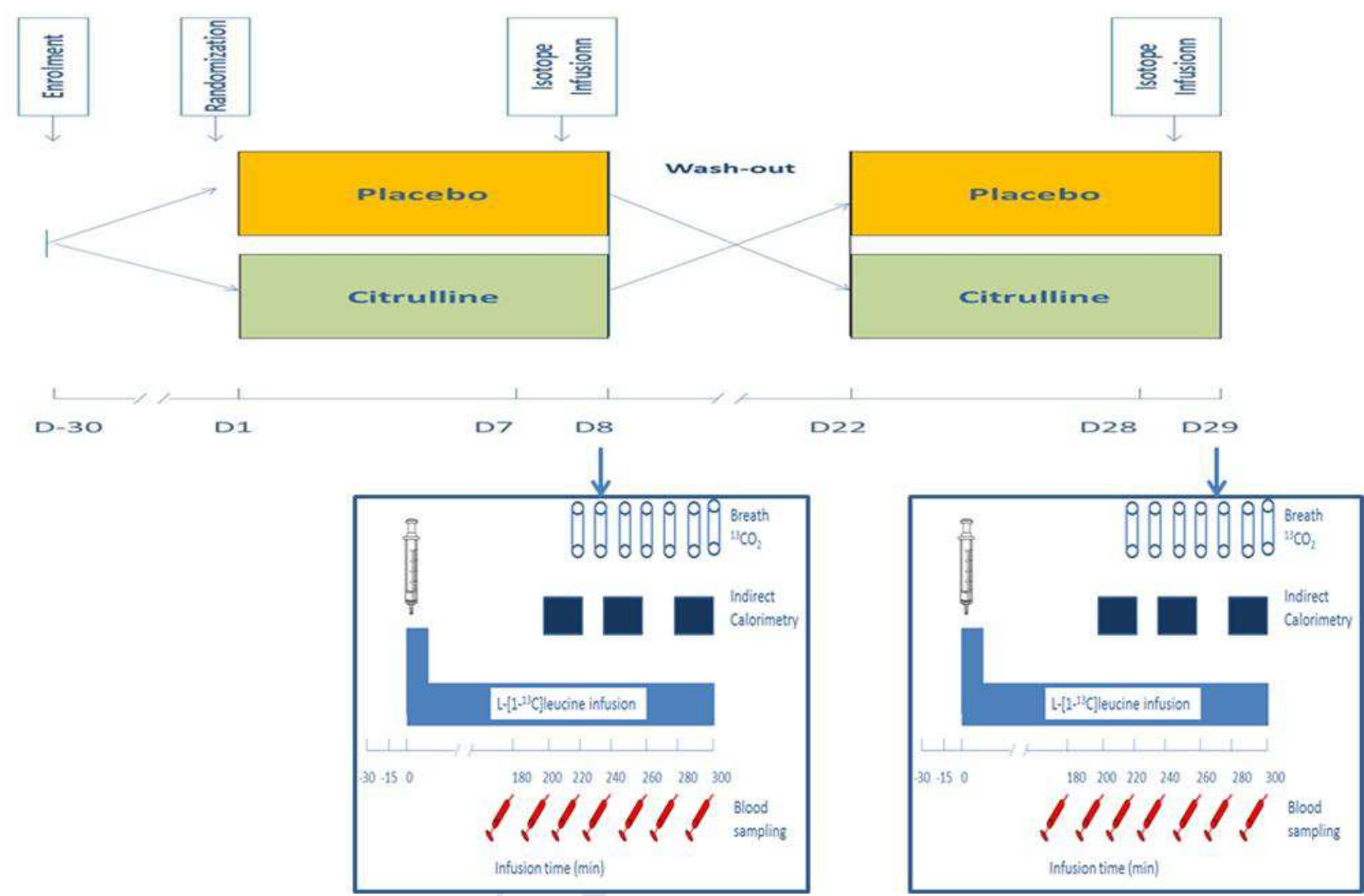
Fig. 2. Flowchart of a double-blind, randomized, placebo-controlled, cross-over trial of oral

in

short

bowel

patients.

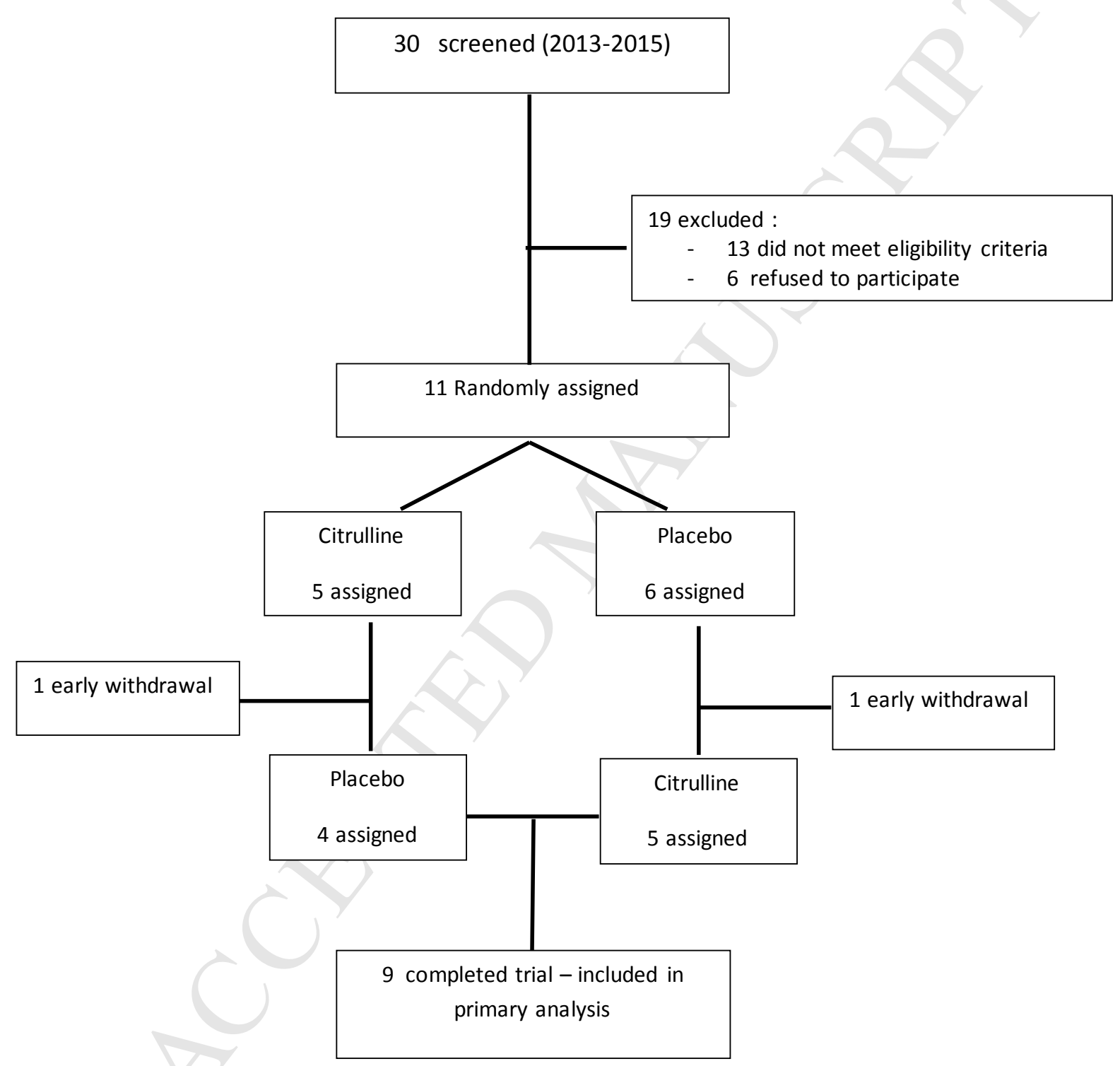


Fig. 3. Effect of citrulline or placebo supplementation on leucine release from protein

450 expressed per kg of body weight. Bars represent mean values \pm SD of 9 patients.

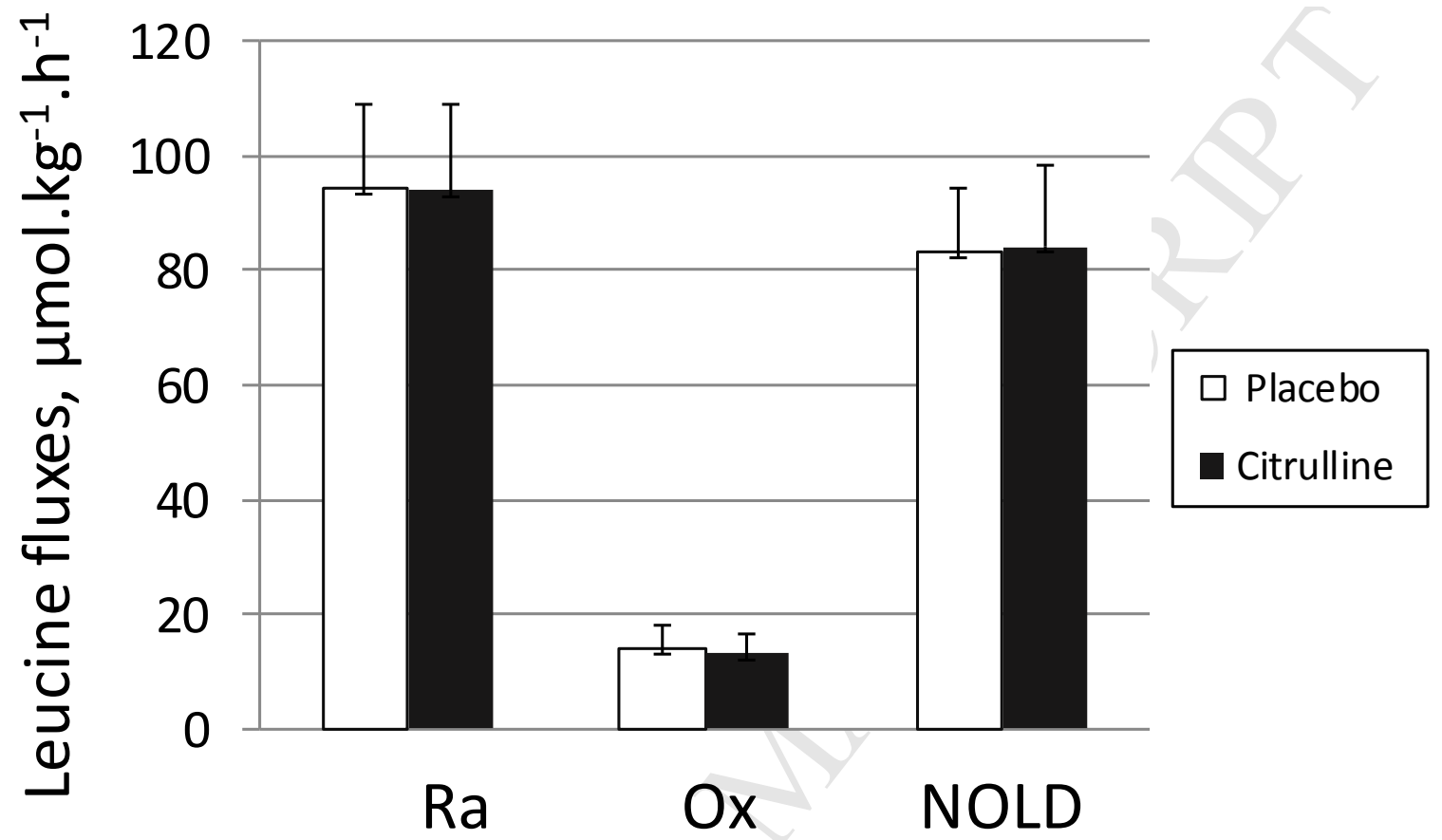

451 
453 Fig. 4. Change in non-oxidative leucine disposal (NOLD, $\mu \mathrm{mol} \cdot \mathrm{kg}^{-1} \cdot \mathrm{h}^{-1}$ ), an index of whole 454 body protein synthesis, between placebo and citrulline supplementation period, after 455 excluding the 2 patients (\#7 and \#9) with baseline plasma citrulline of 39 and $35 \mu \mathrm{mol} / \mathrm{L}$.

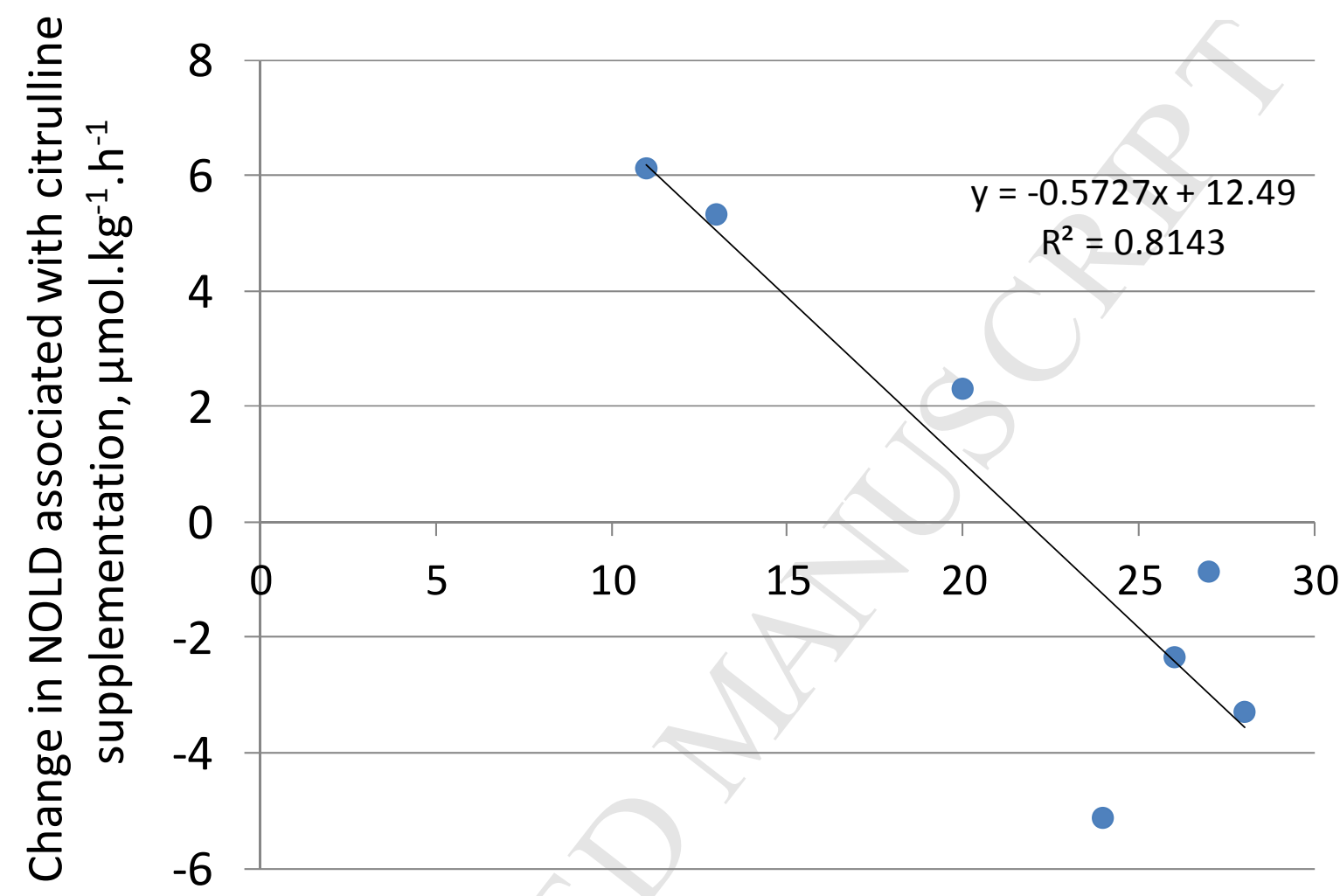

